\title{
Climatic variability and its impact on rice and wheat productivity in Punjab
}

\author{
SUNNY KUMAR*and BALJINDER KAUR SIDANA
}

\author{
Department of Economics and Sociology,Punjab Agricultural University, Ludhiana-141004, Punjab \\ *E-mail-sunnykumar@pau.edu
}

\begin{abstract}
The annual and seasonal (kharif and rabi seasons) trends in temperature (maximum and minimum) and rainfall during 30 years (1986 to 2015) at five locations of Punjab (Bathinda, Faridkot, Ludhiana, SBS Nagar and Patiala) has been analysed. The study revealed that during the last three decades most of the stations experienced significant increase in maximum as well as minimum temperatures in both kharif and rabi seasons. In kharif season maximum temperature positively deviated by $0.12^{\circ} \mathrm{C}$ to $1.34^{\circ} \mathrm{C}$ whereas in wheat growing period the deviation results was from $0.13^{\circ} \mathrm{C}$ to $0.93^{\circ} \mathrm{C}$ at all the locations. The rainfall during kharif season has decreased by 23.2, 27.6, 55.4, 185.4 and 199.6 $\mathrm{mm}$ from normal at Bathinda, Faridkot, Ludhiana, SBS Nagar and Patiala districts, respectively in last three decades. Mann Kendall statistics showed increasing trend in maximum temperature and highlighted that the trend was highly significant in Faridkot, SBS Nagar and Patiala district. To know the impact of climate change quadratic form of regression was applied and the results revealed that the increase in minimum temperature during kharif and rabi season has negative effect on yield of rice and wheat crop in Punjab.
\end{abstract}

Keywords: Minimum and maximum temperature, rainfall, trends, Mann-Kendall statistics.

Understanding meteorological conditions is essential to any agricultural work, because it is very sensitive to global climate changes and therefore, needs to be evaluated. In numerous studies, it is projected that increasing temperature and decline in rainfall may indirectly reduce agricultural production. Punjab is one of the most fertile regions in India. There are many evidences of climate variability in Punjab. The rise in minimum temperature, increased variability in rainfall, decline in average precipitation and increase in relative humidity has serious implications on yields of different crops. The wheat yield declined from the peak of 4.7 tonnes ha-1 in 1999-00 to 4.1 tonnes ha- ${ }^{-1}$ in year 2005-06 due to rise in temperature, especially during the critical periods of growth in the months of January to March (Sidhu et al. 2011). Keeping in view the importance of climate variability on productivity of paddy and wheat in Punjab, the present study is an attempt to analyse the change in climatic pattern and its impact on paddy and wheat productivity in Punjab state.

\section{MATERIALS AND METHODS}

To examine the changing pattern of important climatic variables mainly temperature (maximum and minimum) and rainfall of five different locations of Punjab viz., Bathinda, Fairdkot, Ludhiana, SBS Nagar and Patiala districts for 30 years (1986 to 2015) period were used.
The variability in temperature and rainfall over the three decades were assessed by Mann Kendall test (Mann, 1945; Kendall, 1975). To assess the changing trend of temperature and rainfall on yield of rice and wheat in Punjab, the time series data of maximum temperature, minimum temperature and rainfall was analyzed by fitting different regression models. The quadratic form of regression (without interaction term) was finally chosen after several exercises with linear and log form of equations. To reduce excessive variation in dependent variable that is yield $\left(\mathrm{kg} \mathrm{ha}^{-1}\right)$ of rice and wheat in Punjab, the log form was used. The log value of crop yield was regressed with maximum temperature, minimum temperature, rainfall and square term of each, making a total of 6 explanatory variables.

Quadratic form of regression was applied as under:

$\log y=\beta_{0}+\beta_{1} x_{1}+\beta_{2} x_{2}+\beta_{3} x_{3}+\beta_{4} x_{1} \beta+\beta_{5} x_{2} \beta+\beta_{6} x_{3} \beta+t+\in \ldots \ldots \ldots$ (I)

Where, $\log y=\log$ value of rice and wheat productivity, $\mathrm{x}_{1}=$ maximum temperature; $\mathrm{x}_{2}=$ minimum temperature; $\mathrm{x}_{3}=$ rainfall $; \mathrm{t}=$ trend and $\in=$ error term

In above model, the significance of trend in both the periods suggests the importance of time in explaining the yield of rice and wheat in Punjab. While dealing with time series data, the first step is to check whether the underlying time series is stationary or not. To check unit root in the data, 
Table 1: Seasonal and annual variability of temperature (minimum and maximum) and rainfall from year 1986 to 2015, Punjab.

\begin{tabular}{|c|c|c|c|c|c|c|c|c|c|}
\hline \multirow[t]{2}{*}{ Location } & \multicolumn{3}{|c|}{ Maximum temperature } & \multicolumn{3}{|c|}{ Minimum temperature } & \multicolumn{3}{|c|}{ Rainfall } \\
\hline & Mean $\left({ }^{\circ} \mathrm{C}\right)$ & $\mathrm{d}$ & S-value & Mean $\left({ }^{\circ} \mathrm{C}\right)$ & $\mathrm{d}$ & S-value & $\operatorname{Mean}(\mathrm{mm})$ & $\mathrm{d}$ & S-value \\
\hline \multicolumn{10}{|c|}{ Kharif season (June to September) } \\
\hline Bathinda & 36.2 & 0.49 & $0.002^{\mathrm{NS}}$ & 25.3 & 0.44 & $0.036^{* * *}$ & 220.8 & -23.16 & $-2.985^{\mathrm{NS}}$ \\
\hline Faridkot & 35.3 & 0.33 & $0.035^{* * *}$ & 26.1 & 0.76 & $0.057^{* * *}$ & 318.5 & -27.61 & $-1.885^{\mathrm{NS}}$ \\
\hline Ludhiana & 34.6 & 0.12 & $0.008^{\mathrm{NS}}$ & 25.7 & 0.35 & $0.029^{* * *}$ & 626.3 & -55.42 & $-0.400^{\mathrm{NS}}$ \\
\hline SBS Nagar & 34.2 & 1.34 & $0.05^{* * *}$ & 24.0 & 0.04 & $0.001^{\mathrm{NS}}$ & 834.7 & -185.38 & $-11.930^{* *}$ \\
\hline Patiala & 33.8 & 1.17 & $0.066^{* * *}$ & 24.3 & 1.73 & $0.109^{* * *}$ & 556.3 & -199.64 & $-12.059^{* *}$ \\
\hline \multicolumn{10}{|c|}{ Rabi season (November to March) } \\
\hline Bathinda & 25.0 & 0.05 & $0.025^{\mathrm{NS}}$ & 11.2 & 0.13 & $0.004{ }^{\mathrm{NS}}$ & 51.6 & -6.47 & $-0.376^{\mathrm{NS}}$ \\
\hline Faridkot & 25.8 & 0.70 & $0.048^{* * *}$ & 11.8 & 0.87 & $0.059 \mathrm{NS}$ & 69.4 & -3.00 & $0.500^{\mathrm{NS}}$ \\
\hline Ludhiana & 24.1 & 0.32 & $0.007^{\mathrm{NS}}$ & 11.4 & 0.36 & $0.031^{* * *}$ & 135.1 & 20.35 & $-0.743^{\mathrm{NS}}$ \\
\hline SBS Nagar & 25.1 & 0.67 & $0.04^{* * *}$ & 10.9 & 0.11 & $0.020^{\mathrm{NS}}$ & 169.7 & -25.00 & $-0.695^{\mathrm{NS}}$ \\
\hline Patiala & 24.3 & 1.33 & $0.053^{* * *}$ & 10.7 & 0.93 & $0.089^{* * *}$ & 83.7 & -23.37 & $-1.750^{\mathrm{NS}}$ \\
\hline \multicolumn{10}{|l|}{ Annual } \\
\hline Bathinda & 30.8 & 0.11 & $0.003^{\mathrm{NS}}$ & 16.9 & 0.29 & $0.029^{* * *}$ & 296.5 & -40.52 & $-3.983^{\mathrm{NS}}$ \\
\hline Faridkot & 30.2 & 0.66 & $0.044^{* * *}$ & 17.2 & 0.65 & $0.072^{* * *}$ & 410.5 & -28.80 & $-2.280^{\mathrm{NS}}$ \\
\hline Ludhiana & 29.7 & 0.37 & $0.008^{\mathrm{NS}}$ & 17.1 & 0.53 & $0.041^{* * *}$ & 898.5 & -44.00 & $-0.595^{\mathrm{NS}}$ \\
\hline SBS Nagar & 30.0 & 0.66 & $0.044^{* * *}$ & 16.2 & 0.29 & $0.014^{\mathrm{NS}}$ & 1057.2 & -205.15 & $-11.200^{* *}$ \\
\hline Patiala & 29.4 & 1.43 & $0.074^{* * *}$ & 16.6 & 1.59 & $0.114^{* * *}$ & 672.4 & -224.00 & $-14.375^{* *}$ \\
\hline
\end{tabular}

Notes: $* * *, * *$ and $*$ denote significance at 1,5 and 10 percent levels, respectively, $\mathrm{d}=$ deviations $=$ Sen-slope

augmented Dickey- Fuller (ADF) test was used. The analysis

of the unit root test proved that the data used for regression analysis were stationary at lag 1 from year 1986 to 2015.

\section{RESULTS AND DISCUSSION}

\section{Climatic variability during kharif season}

During the study period, Punjab has faced maximum temperature at peak level during the year $1987\left(37^{\circ} \mathrm{C}\right)$, lowest has been received during year $1996\left(33.7^{\circ} \mathrm{C}\right)$. During kharif season, the minimum temperature ranged between $24.0^{\circ} \mathrm{C}$ to $26.1^{\circ} \mathrm{C}$ with average value of $25.1^{\circ} \mathrm{C}$ (Table 1 ). Overall, the maximum temperature during rice growing period showed the deviation of $0.12^{\circ} \mathrm{C}$ to $1.34^{\circ} \mathrm{C}$ from the normal across the locations of Punjab. During June to September, the highest deviation from normal in minimum temperature has been observed in Patiala district $\left(1.73^{\circ} \mathrm{C}\right)$ whereas SBS Nagar district exhibited the lowest deviation of $0.04{ }^{\circ} \mathrm{C}$ from normal (Table 1). SBS Nagar recorded highest average rainfall $(834.7 \mathrm{~mm})$ followed by Ludhiana $(626.3 \mathrm{~mm})$ and Patiala $(556.3 \mathrm{~mm})$. In general, the rainfall during kharif season had decreased by 23.1, 27.6, 55.4, 185.4 and 199.6 $\mathrm{mm}$ from normal at Bathinda, Fairdkot, Ludhiana, SBS Nagar and Patiala districts, respectively in last three decades.

\section{Climatic variability during rabi season}

During rabi season (November to March), the average maximum temperature recorded at different locations in ascending order of magnitude are Ludhiana $\left(24.1^{\circ} \mathrm{C}\right)$, Patiala $\left(24.3^{\circ} \mathrm{C}\right)$, Faridkot $\left(25.8^{\circ} \mathrm{C}\right)$, Bathinda $\left(25.0^{\circ} \mathrm{C}\right)$ and SBS Nagar $\left(25.1^{\circ} \mathrm{C}\right)$. The minimum temperature ranged between $10.9^{\circ} \mathrm{C}$ to $11.8^{\circ} \mathrm{C}$ with average value of $11.2^{\circ} \mathrm{C}$ at all the selected locations of Punjab (Table 1). During November till March, the deviation in minimum temperature ranged between $0.13^{\circ} \mathrm{C}$ to $0.93^{\circ} \mathrm{C}$ from the normal at different locations of Punjab. Rainfall ranged between $51.6 \mathrm{~mm}$ to $169.7 \mathrm{~mm}$ with an average value of $102 \mathrm{~mm}$ across the locations in Punjab. In general, the rainfall during winter season deviated negatively by 3 to $25 \mathrm{~mm}$ at different locations of Punjab.

\section{Annual variability}

The annual maximum and minimum temperatures in last three decades ranged between $29.4^{\circ} \mathrm{C}$ to $30.8^{\circ} \mathrm{C}$ and $16.2^{\circ} \mathrm{C}$ to $17.2^{\circ} \mathrm{C}$ with average values of $30.0^{\circ} \mathrm{C}$ and 
Table 2: Estimates of regressing rice and wheat yield on temperature, rainfall and their quadratic terms in Punjab

\begin{tabular}{|c|c|c|c|c|}
\hline Particulars & Coefficients & Standard error & $\mathrm{p}$-value & t- value \\
\hline \multicolumn{5}{|c|}{ Rice yield model } \\
\hline Constant & $0.6548^{\mathrm{NS}}$ & 1.4239 & 0.6463 & 0.4598 \\
\hline $\mathrm{X}_{1}\left(\mathrm{~T}_{\max }\right)$ & $-0.0506^{\mathrm{NS}}$ & 0.0796 & 0.5260 & -0.6360 \\
\hline $\mathrm{X}_{1}^{2}\left(\mathrm{~T}_{\max }\right)^{2}$ & $0.0007^{\mathrm{NS}}$ & 0.0011 & 0.5454 & 0.6061 \\
\hline $\mathrm{X}_{2}\left(\mathrm{~T}_{\min }\right)$ & $0.2803^{* * *}$ & 0.0475 & $2.55468 \mathrm{e}-08$ & 5.8993 \\
\hline $\mathrm{X}_{2}^{2}\left(\mathrm{~T}_{\min }\right)^{2}$ & $-0.0051^{* * *}$ & 0.0009 & $7.72779 \mathrm{e}-08$ & -5.6690 \\
\hline $\mathrm{X}_{3}$ (Rainfall) & $-1.96519 \mathrm{e}-05^{\mathrm{NS}}$ & $3.90552 \mathrm{e}-05$ & 0.6156 & -0.5030 \\
\hline $\mathrm{X}_{3}^{2}(\text { Rainfall })^{2}$ & $6.4055 \mathrm{e}-10^{\mathrm{NS}}$ & $2.32951 \mathrm{e}-08$ & 0.9780 & 0.0275 \\
\hline Trend & $0.0002^{*}$ & 0.0001 & 0.0582 & 1.9195 \\
\hline \multicolumn{5}{|c|}{ Wheat yield model } \\
\hline Constant & $4.4328^{\mathrm{NS}}$ & 1.7376 & 0.0118 & 2.551 \\
\hline $\mathrm{X}_{1}\left(\mathrm{~T}_{\max }\right)$ & $0.1495^{\mathrm{NS}}$ & 0.1385 & 0.2821 & 1.080 \\
\hline $\mathrm{X}_{1}^{2}\left(\mathrm{~T}_{\max }\right)^{2}$ & $-0.0038^{\mathrm{NS}}$ & 0.0030 & 0.2109 & -1.257 \\
\hline $\mathrm{X}_{2}\left(\mathrm{~T}_{\min }\right)$ & $-0.5279^{* * *}$ & 0.1839 & 0.0047 & -2.871 \\
\hline $\mathrm{X}_{2}^{2}\left(\mathrm{~T}_{\min }\right)^{2}$ & $0.0308^{* * *}$ & 0.0104 & 0.0037 & 2.949 \\
\hline $\mathrm{X}_{3}$ (Rainfall) & $-0.0009^{* * *}$ & 0.0002 & $6.22 \mathrm{e}-06$ & -4.695 \\
\hline $\mathrm{X}_{3}^{2}(\text { Rainfall })^{2}$ & $2.44477 \mathrm{e}-06^{* * *}$ & $6.9645 \mathrm{e}-07$ & 0.0006 & 3.510 \\
\hline Trend & $0.0007^{* * *}$ & 0.0001 & $4.72 \mathrm{e}-10$ & 6.691 \\
\hline
\end{tabular}

Notes: ${ }^{* *}, * *$ and $*$ denote significance at 1,5 and 10 percent levels, respectively; NS=Non-Significant, Tmax $=$ maximum temperature, $\mathrm{Tmin}=$ minimum temperature

$16.8^{\circ} \mathrm{C}$, respectively. Annual rainfall was more at SBS Nagar (1057 mm) followed by Ludhiana $(898 \mathrm{~mm})$, Patiala (672 $\mathrm{mm})$, Faridkot (411 $\mathrm{mm})$ and Bathinda $(297 \mathrm{~mm})$ in succession. Overall, annual rainfall had decreased by $28.8,40.5,44.0$ 205.2 and $224.0 \mathrm{~mm}$ from normal at Faridkot, Bathinda, Ludhiana, SBS Nagar and Patiala districts, respectively (Table 1).

\section{Mann Kendall trend analysis}

The Mann Kendall statistics showed that, there is increasing trend in maximum temperature in both kharif and rabi seasons at all the locations of Punjab, but the trend was highly significant in Faridkot, SBS Nagar and Patiala districts. Similar trend was observed in the annual variation of maximum temperature. Significant increasing trend in minimum temperature is observed in kharif season, at all the locations of Punjab except SBS Nagar, while in rabi season the minimum temperature had increasing trend at all the locations which was highly significant at Ludhiana and Patiala district.The gradual increase in the maximum and minimum temperature was also reported by Hundal and Kaur (2002). Kaur et al.(2006) reported that in Ludhiana (Punjab) the maximum temperature has remained near normal over the past three decades. The annual and kharif season maximum temperature revealed a slight decreasing trend while in $\mathrm{rabi}$ season maximum temperature revealed a slight increasing trend.

The significant declining trend in annual and monsoon rainfall has been observed in SBS Nagar and Patiala district, but winter rainfall didn't show any significant change over the years at all the locations of Punjab. Hundal et al. (1997) revealed that an annual rainfall showed decreasing trend at Ballowal, Saunkhri and Bathinda while a little increasing trend at Ludhiana. The upward trend in maximum and minimum temperature and downward trend in rainfall as indicated by Mann-Kendall statistics, undergone significant changes during last three decades posing threats to yield of major crops grown in Punjab state.

\section{Impact of climate variability on rice and wheat yield}

To account for non-linear effects, we have included the minimum and maximum temperature, rainfall and squared term of each in the regression analysis. The model was 
estimated as log-linear to reduce excessive variation in the dependent variable that is yield $\left(\mathrm{kg} \mathrm{ha}^{-1}\right)$ of rice and wheat in Punjab state. The coefficients of this functional form are easily interpretable as proportionate changes. The data used for regression analysis were stationary at lag 1 from year 1986 to 2015 (Table 2).

The results revealed that the coefficient of minimum temperature is positive whereas the square term of minimum temperature is negative and also significant, which means that increase in minimum temperature from the long run average (1986-2015) initially affects the yield of rice positively, but subsequent increase in temperature affects yield of rice adversely. On the other hand, maximum temperature shows the non-significant effect on yield of rice crop. Itclearly indicates that it is the minimum temperature and not maximum temperature that affects the yield of rice crop. The effect of rise in maximum temperature has been lessened or even minimized through assured irrigation in Punjab state, which has led to the over-use of groundwater resources.

In wheat growing period, the estimated coefficient for minimum temperature is negative though it is weak; but square of temperature is positive (Table 2). Some of the weaknesses of the estimated minimum temperature is also on account of too much of fluctuations in the minimum temperature in the month of March. The estimated coefficients suggest that increase in the minimum temperature from the long run average temperature of the concerned months has negative effect on the yield of wheat in Punjab. Furthermore, the coefficient of rainfall has found to be negatively significant in wheat growing period, meaning thereby that excess rainfall is having derogatory effects on the wheat yield. The above result to some extent is in line with the simulation based study (Singh et al., 2008).

\section{CONCLUSIONS}

The minimum temperature during kharif season showed significant increasing $\left(0.02^{\circ} \mathrm{C}\right.$ per year $)$ trend at different locations of Punjab except SBS Nagar, while in winter season minimum temperature had increasing trend. In rice growing period maximum temperature positively deviated by $0.12^{\circ} \mathrm{C}$ to $1.34^{\circ} \mathrm{C}$ whereas in wheat growing period the deviation results was from $0.13^{\circ} \mathrm{C}$ to $0.93^{\circ} \mathrm{C}$ at all the locations of Punjab. Following the above changes in temperature and rainfall and its effects on rice and wheat crop certain ameliorative measures are desired.

\section{REFERENCES}

Hundal, S., Kaur, P., and Mahi, G. S. (1997). Variability and trend changes in rainfall of Ludhiana, Punjab. In: Pro. TROPMET-1997 on Monsoon, Climate and Agriculture, Indian Institute of Sciences, Bangalore, 10-14 February.

Hundal S.S. and Kaur, P. (2002). Annual and seasonal climatic variability at different locations of Punjab state. $J$. Agrometeorol.,4: 113-25.

Hundal, S.S. and Kaur, P. (2006). Climatic variability and its impact on cereal productivity in Indian Punjab. Current Sci.,92:pp. 508-12.

Kendall, M. G. (1975). Rank correlation Methods, $4^{\text {th }}$ edition, Charles Griffin, London, U K.

Kaur, Prabhjot and Hundal, S.S. (2006). Effect of possible futuristic climate change scenarios on productivity of some kharif and rabi crops in the central agroclimatic zone of Punjab J. Agric. Physics, 6: 21-27.

Mann, H. B. (1945). Non-parametric test against trend. Econometrica. 13:245-59.

Sidhu, R. S., Vatta, Kamal and Upmanu, Lal (2011). Climate change impact and management strategies for sustainable water-energy-agriculture output in Punjab. Ind. J. Agri. Econ. 66:328-39.

Singh Harpreet, S. S. Hundal and Prabhjyot Kaur (2008). Effect of temperature and rainfall on wheat yield in south western regon of Punjab, J. Agrometeorol.,10: 70- 74. 